NASA/TM-2008-215422

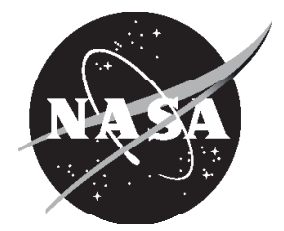

\title{
The Effect of Spray Initial Conditions on Heat Release and Emissions in LDI CFD Calculations
}

Anthony C. Iannetti and Nan-Suey Liu

Glenn Research Center, Cleveland, Ohio

Farhad Davoudzadeh

Air Force Research Laboratory, Edwards Air Force Base, California 


\section{NASA STI Program . . . in Profile}

Since its founding, NASA has been dedicated to the advancement of aeronautics and space science. The NASA Scientific and Technical Information (STI) program plays a key part in helping NASA maintain this important role.

The NASA STI Program operates under the auspices of the Agency Chief Information Officer. It collects, organizes, provides for archiving, and disseminates NASA's STI. The NASA STI program provides access to the NASA Aeronautics and Space Database and its public interface, the NASA Technical Reports Server, thus providing one of the largest collections of aeronautical and space science STI in the world. Results are published in both non-NASA channels and by NASA in the NASA STI Report Series, which includes the following report types:

- TECHNICAL PUBLICATION. Reports of completed research or a major significant phase of research that present the results of NASA programs and include extensive data or theoretical analysis. Includes compilations of significant scientific and technical data and information deemed to be of continuing reference value. NASA counterpart of peer-reviewed formal professional papers but has less stringent limitations on manuscript length and extent of graphic presentations.

- TECHNICAL MEMORANDUM. Scientific and technical findings that are preliminary or of specialized interest, e.g., quick release reports, working papers, and bibliographies that contain minimal annotation. Does not contain extensive analysis.

- CONTRACTOR REPORT. Scientific and technical findings by NASA-sponsored contractors and grantees.

- CONFERENCE PUBLICATION. Collected papers from scientific and technical conferences, symposia, seminars, or other meetings sponsored or cosponsored by NASA.

- SPECIAL PUBLICATION. Scientific, technical, or historical information from NASA programs, projects, and missions, often concerned with subjects having substantial public interest.

- TECHNICAL TRANSLATION. Englishlanguage translations of foreign scientific and technical material pertinent to NASA's mission.

Specialized services also include creating custom thesauri, building customized databases, organizing and publishing research results.

For more information about the NASA STI program, see the following:

- Access the NASA STI program home page at http://www.sti.nasa.gov

- E-mail your question via the Internet to help@ sti.nasa.gov

- Fax your question to the NASA STI Help Desk at 301-621-0134

- Telephone the NASA STI Help Desk at 301-621-0390

- Write to: NASA Center for AeroSpace Information (CASI) 7115 Standard Drive Hanover, MD 21076-1320 
NASA/TM-2008-215422

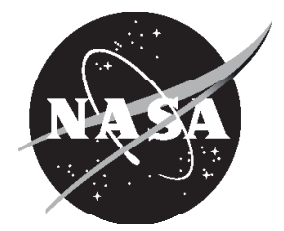

\section{The Effect of Spray Initial Conditions on Heat Release and Emissions in LDI CFD Calculations}

Anthony C. Iannetti and Nan-Suey Liu

Glenn Research Center, Cleveland, Ohio

Farhad Davoudzadeh

Air Force Research Laboratory, Edwards Air Force Base, California

National Aeronautics and

Space Administration

Glenn Research Center

Cleveland, Ohio 44135 


\section{Acknowledgments}

We would like to Jeffery Moder for his valuable advice. This work was funded by the Subsonic Fixed Wing and Supersonic Fixed Wing programs in Aeronautics Research Mission Directorate.

This report contains preliminary findings, subject to revision as analysis proceeds.

Trade names and trademarks are used in this report for identification only. Their usage does not constitute an official endorsement, either expressed or implied, by the National Aeronautics and Space Administration.

This work was sponsored by the Fundamental Aeronautics Program at the NASA Glenn Research Center.

Level of Review: This material has been technically reviewed by technical management.

Available from

NASA Center for Aerospace Information 7115 Standard Drive

Hanover, MD 21076-1320
National Technical Information Service 5285 Port Royal Road Springfield, VA 22161 


\title{
The Effect of Spray Initial Conditions on Heat Release and Emissions in LDI CFD Calculations
}

\author{
Anthony C. Iannetti and Nan-Suey Liu \\ National Aeronautics and Space Administration \\ Glenn Research Center \\ Cleveland, Ohio 44135 \\ Farhad Davoudzadeh \\ Air Force Research Laboratory \\ Edwards Air Force Base, California 93524-7680
}

\begin{abstract}
The mass and velocity distribution of liquid spray has a primary effect on the combustion heat release process. This heat release process then affects emissions like Nitrogen Oxides $\left(\mathrm{NO}_{\mathrm{x}}\right)$ and Carbon Monoxide (CO). Computational Fluid Dynamics gives the engineer insight into these processes, but various setup options exist (number of droplet groups, initial droplet temperature) for spray initial conditions. This paper studies these spray initial condition options using the National Combustion Code (NCC) on a single swirler Lean Direct Injection (LDI) flame tube. Using laminar finite rate chemistry, comparisons are made against experimental data for velocity measurements, temperature, and emissions $\left(\mathrm{NO}_{\mathrm{x}}, \mathrm{CO}\right)$.
\end{abstract}

\section{Introduction}

The use of combustion Computational Fluid Dynamics (CFD) in the development of combustion technology has been greatly facilitated by the advancements made during the last decade in the areas of combustion modeling, numerical simulation, and computing platform. Further development of verification, validation, and uncertainty quantification will profoundly impact the reliability and utility of these modeling and simulation tools. Under the NASA Fundamental Aeronautics Program, an assessment of existing computational tools for emissions and flow field is being carried out. As a first step, the present effort aims at establishing the baseline for prediction methods and experimental data for Lean Direct Injection (LDI) (refs. 1, 2, and 3) combustion in confined, swirling flows. Combustion codes based on Reynolds Averaged Navier-Stokes (RANS), Very Large Eddy Simulation (VLES), and traditional Large Eddy Simulation (LES) will be used; the present paper reports the preliminary investigation using the National Combustion Code (NCC).

The National Combustion Code (NCC) is a state of the art CFD program specifically designed for combustion processes. A short summary of the features of the NCC pertaining to this paper are: the use of unstructured grids (ref. 4), massively parallel computing - with almost perfectly linear scalability, (refs. 5 and 6) a dynamic wall function with the effect of adverse pressure gradient (ref. 7) low Reynolds number wall treatment, (ref. 8), and a cubic non-linear k- $\varepsilon$ turbulence model (refs. 9 and 10), Lagrangian liquid phase spray model (ref. 11), and stiff laminar chemistry integration. Recently, viscous low-speed preconditioning (refs. 12 and 13), has been added to improve the low-speed convergence of the NCC in viscous regions, and the ability to handle multiple sets of periodic boundary conditions has also been added. The combination of these features is usually not available in other CFD codes and gives the NCC an advantage when computing recirculating, turbulent, reacting, spray flows. Previously, the NCC has undergone extensive validation studies for simple flows (refs. 14 and 15), complex flows (ref. 16), $\mathrm{NO}_{\mathrm{x}}$ emissions prediction performance (ref. 17), and traditional gas turbine combustor/injectors (ref. 18).

This paper extends the LDI combustion CFD analysis of Davoudzadeh (refs. 19 and 20). Where previous work only looked at non-reacting flows, this paper will compare the NCC using a steady-state RANS approach against experimental data for a confined, reacting spray flow. This paper will show the sensitivity to the spray initial conditions, particularly the number of droplet groups used to define the distribution, and the initial temperature. 


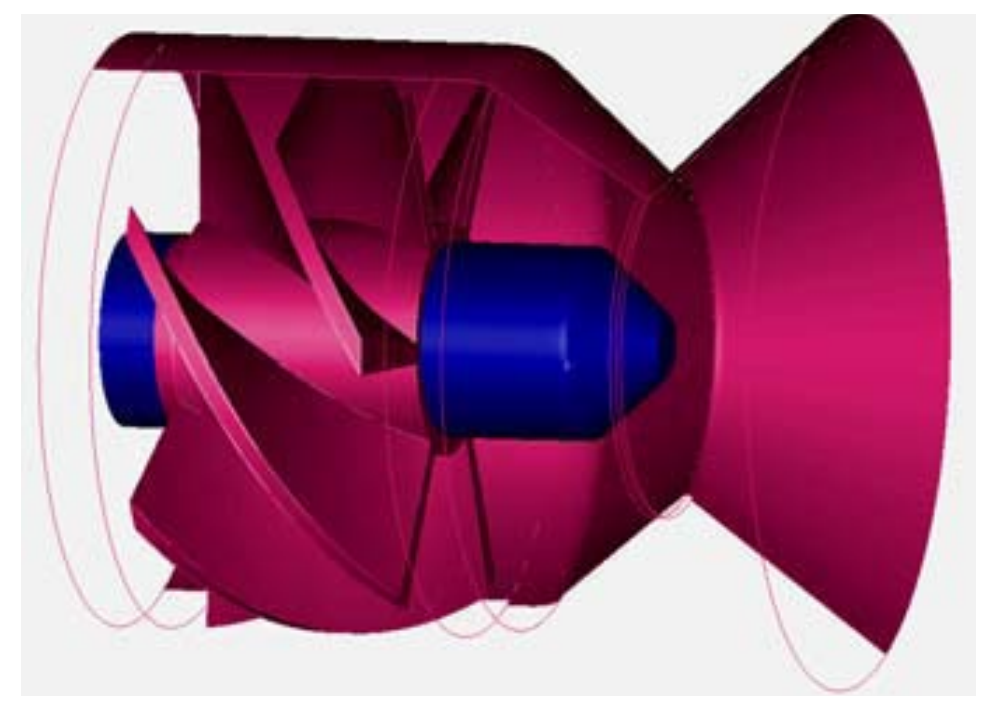

Figure 1.-Single element LDI injector geometry.

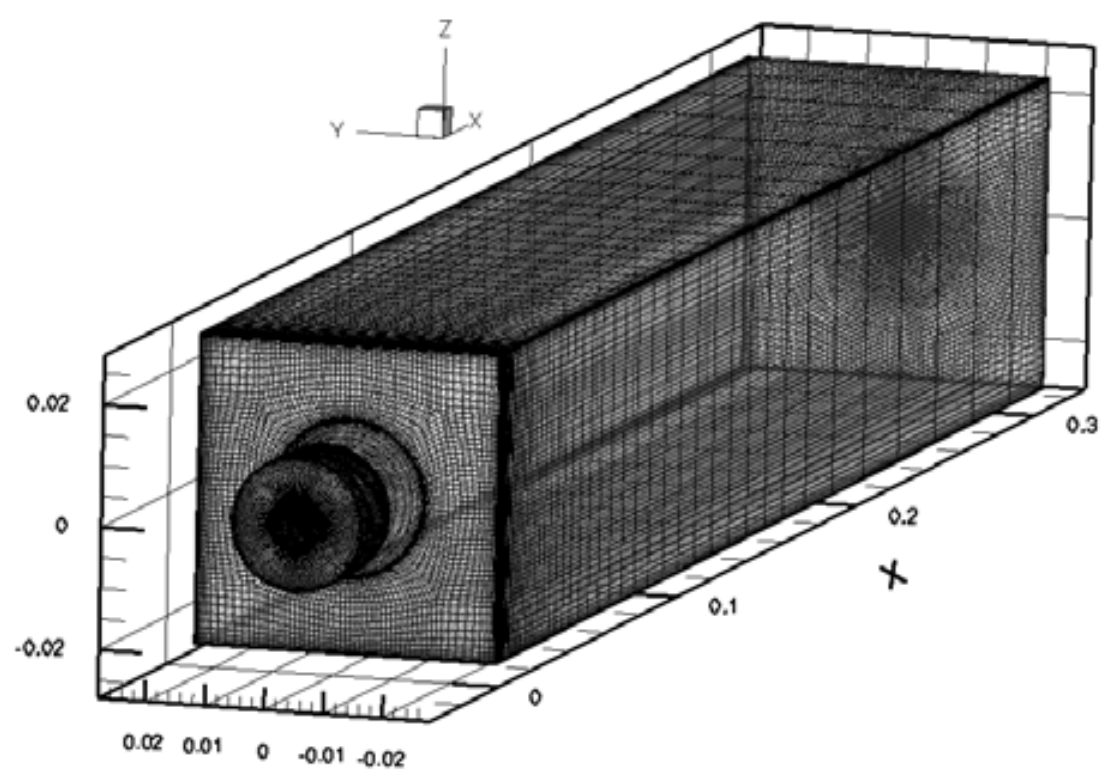

Figure 2.-Computational grid for the single element LDI combustor.

\section{Flow Modeling}

\section{A. Geometry and Mesh Generation}

The single-element LDI swirler configuration is illustrated in Figure 1. Each element consists of an air passage with an upstream air swirler and a converging-diverging venturi section. The fuel is injected through the center of swirler and the fuel tip is at the throat of the venture. The air swirlers have helical, axial vanes with downstream vane angles of $60^{\circ}$. There are six vanes with an inside diameter of $9.3 \mathrm{~mm}$ and an outside diameter of $22.1 \mathrm{~mm}$. The air then dumps into a 50.8 by $50.8 \mathrm{~mm}$ combustion section.

Since the NCC allows for unstructured elements, the grid may be composed of any type and mix of threedimensional elements. However, hexahedral elements were chosen because they are more efficient at filling a volume with a smaller number of elements compared to an all tetrahedral grid. Hexahedral elements also allow a better calculation of the normal derivatives that are crucial for accurate boundary layer resolution. Approximately 850,000 elements were used. The "Gridgen" mesh generation software was used to create all the grids used in the numerical simulation reported in this paper. 


\section{B. Air Flow Conditions}

An inlet boundary condition is used, with the air flow speed $(20.14 \mathrm{~m} / \mathrm{s})$ normal to the inlet face, density $\left(1.19 \mathrm{Kg} / \mathrm{m}^{3}\right)$, turbulence intensity level (approximately 5 percent), turbulence mixing length $(0.15 \mathrm{~m})$, and static temperature $\left(294.28^{\circ} \mathrm{K}\right)$. The inlet pressure in these boundary conditions are calculated, not specified (because they are subsonic). The exit boundary condition for single-element specifies static pressure. The operating pressure of the combustor is approximately $1 \mathrm{~atm}$, while the equivalence ratio is 0.75 . The measured pressure drop (as a percentage of P3) during the experiments was measured at 4 percent.

\section{Liquid Spray Conditions}

The spray evaporation process was modeled as a Lagrangian particle, where each particle represents a group of actual spray droplets. The droplets are represented as a group rather than an individual droplet because calculating each droplet is impractical, as it is too computationally intense. From examining the spray experimental data, a Sauter Mean Diameter (SMD, $\mathrm{D}_{32}$ ) of $32 \mu \mathrm{m}$ was used for all calculations. The hollow spray cone had a total angle of $90.0^{\circ}$ and a cone thickness of $14.0^{\circ}$. A mass flow of $4.15 \times 10^{-4} \mathrm{~kg} / \mathrm{s}$ and an initial velocity of $20.0 \mathrm{~m} / \mathrm{s}$ was prescribed. Simulations were performed with three, nine, and eighteen droplet groups. Figure 3 shows the cumulative dropsize distribution (given by Raju (ref. 11)) used as the spray initial condition. Three droplet groups is not an adequate representation of the spray distribution; this was used as starting point for calculations. Using nine and eighteen droplet groups, the drop size distribution is represented accurately. A well represented (nine droplet groups and above) distribution at a $32 \mu \mathrm{m} \mathrm{SMD} \mathrm{has} \mathrm{a} \mathrm{droplet} \mathrm{size} \mathrm{range} \mathrm{from} 1$ to $95 \mu \mathrm{m}$. Ninety-six streams and 32 rays were used for the spatial distribution for the spray. The Lagrangian solution process uses an "unsteady" spray model. Droplet groups are only integrated for a fraction of their lifetime (but restarted at this point for the next iteration), rather than completely to steady-state. A time step of $5.0 \times 10^{-7}$ was used as the integration time step (DTML in NCC terminology), and an integration time of $1.0 \times 10^{-4}$ (DGML). New droplet groups were introduced every integration time. This process is thought to allow better load balancing on parallel computing platforms, possibly allow better coupling with the CFD solver.

$\mathrm{SMD}=32, \mathrm{dD}=0.2, \mathrm{Dmax}=3 * \mathrm{SMD}=96$ micrometers

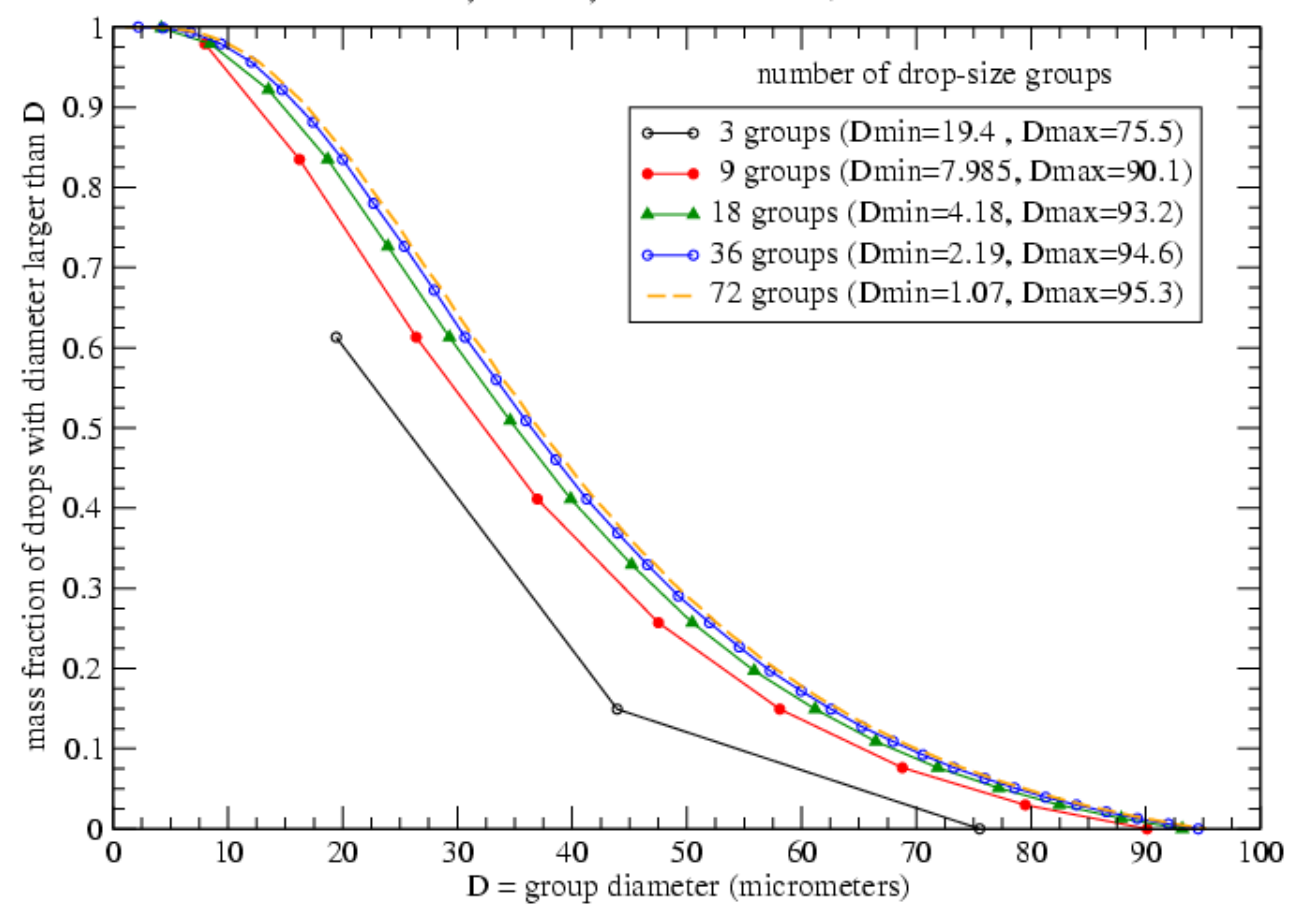

Figure 3.-Cumulative drop size distribution (spray initial condition). 


\section{Chemistry Model}

Ideally, we would prefer to use detailed chemical kinetic models. There are two problems with this approach: 1) Jet-A is a fuel and not a substance, and there are no universally accepted surrogate fuel models for Jet-A; 2) the computational costs associated with these models make them impractical when fine computational grids are used. Originally, a single-step, global chemistry model was used, shown in Table 1 . This model was based on propane kinetics (ref. 21), which are close to Jet-A's reaction rates. The single-step model allowed an easier start up in the solution process, by reducing the computational requirements during the ignition phase. Single-step models do not allow emissions calculations, only heat release. Because of this, a reduced ten-step, twelve species model based on propane kinetics (refs. 22 and 23) was used, as shown in Table 2. The mechanism was developed by a gradual reduction of reaction steps and species using sensitivity techniques. The reduced mechanism also describes the formation of Carbon Monoxide and Nitrogen Oxide. However, only one nitrogen-oxide species, NO, has been used in the reduced mechanism. NO in the reduced mechanism represents the whole family of nitrogen oxides including nitric oxide by Zeldovich (ref. 24) reactions, prompt NO reactions by Fenimore (ref. 25) and nitrogen oxide formation through nitrous oxide.

TABLE 1.-SINGLE STEP (GLOBAL) CHEMISTRY MODEL

\begin{tabular}{|c|c|c|c|c|}
\hline & Reaction & $\begin{array}{c}\mathbf{A}, \\
\text { mole }-\mathbf{c m}-\text { sec- } \mathbf{K}\end{array}$ & n & $\begin{array}{c}\mathrm{E}, \\
\text { cal } / \text { mole }\end{array}$ \\
\hline 1 & $\begin{array}{c}\mathbf{4} \mathbf{C}_{\mathbf{1 2}} \mathbf{H}_{\mathbf{2 3}}+\mathbf{7 1} \mathbf{O}_{\mathbf{2}}=>\mathbf{4 8} \mathbf{C O}_{\mathbf{2}}+\mathbf{4 6} \mathbf{H}_{\mathbf{2}} \mathrm{O} \\
\mathrm{GLO} / \mathrm{C}_{12} \mathrm{H}_{23} 0.10 / \\
\mathrm{GLO} / \mathrm{O}_{2} 1.65 /\end{array}$ & $8.60 \times 10^{11}$ & 0.00 & $3.00 \times 10^{4}$ \\
\hline
\end{tabular}

TABLE 2.-REDUCED 10 STEP, 12 SPECIES CHEMISTRY MODEL IN CHEMKIN FORMAT

\begin{tabular}{|l|l|c|c|c|}
\hline & \multicolumn{1}{|c|}{ Reaction } & $\begin{array}{c}\mathbf{A}, \\
\mathbf{m o l e}-\mathbf{c m}-\mathbf{s e c}-\mathbf{K}\end{array}$ & $\mathbf{n}$ & $\begin{array}{c}\mathbf{E} \\
\mathbf{c a l} / \mathbf{m o l e}\end{array}$ \\
\hline 1 & $\begin{array}{c}\mathbf{4} \mathbf{C}_{12} \mathbf{H}_{23}+\mathbf{4 7} \mathbf{O}_{2}=>\mathbf{4 8} \mathbf{C O}+\mathbf{4 6} \mathbf{H}_{2} \mathbf{O} \\
\mathrm{GLO} / \mathrm{C}_{12} \mathrm{H}_{23} 0.1 /\end{array}$ & $1.46 \times 10^{13}$ & 0.00 & $3.40 \times 10^{4}$ \\
\hline $\mathrm{GLO} / \mathrm{O}_{2} 1.6 /$ & & & \\
\hline 2 & $\mathbf{H}_{2}+\mathbf{O}_{2}<=>\mathbf{H}_{2} \mathbf{O}+\mathbf{O}$ & $3.98 \times 10^{11}$ & 1.00 & $4.80 \times 10^{4}$ \\
\hline 3 & $\mathbf{H}_{\mathbf{2}}+\mathbf{O}<=>\mathbf{H}+\mathbf{O H}$ & $3.00 \times 10^{14}$ & 0.00 & $6.00 \times 10^{3}$ \\
\hline 4 & $\mathbf{H}+\mathbf{O}_{2}<=>\mathbf{O}+\mathbf{O H}$ & $4.00 \times 10^{14}$ & 0.00 & $1.80 \times 10^{4}$ \\
\hline 5 & $\mathbf{C O}+\mathbf{O H}<=>\mathbf{C O} \mathbf{O}_{2}+\mathbf{H}$ & $1.51 \times 10^{07}$ & 1.28 & $-7.58 \times 10^{2}$ \\
\hline 6 & $\mathbf{H}_{2} \mathbf{O}+\mathbf{O}_{2}<=>\mathbf{2 O}+\mathbf{H}_{2} \mathbf{O}$ & $3.17 \times 10^{12}$ & 2.00 & $1.12 \times 10^{5}$ \\
\hline 7 & $\mathbf{C O}+\mathbf{H}_{2} \mathbf{O}<=>\mathbf{C O} \mathbf{O}_{2}+\mathbf{H}_{2}$ & $5.50 \times 10^{4}$ & 1.28 & $-1.00 \times 10^{3}$ \\
\hline 8 & $\mathbf{N}_{2}+\mathbf{O}<=>\mathbf{N}+\mathbf{N O}$ & $1.00 \times 10^{14}$ & 0.00 & $7.50 \times 10^{4}$ \\
\hline 9 & $\mathbf{N}+\mathbf{O}_{2}<=>\mathbf{N O}+\mathbf{O}$ & $6.30 \times 10^{9}$ & 1.10 & $6.28 \times 10^{3}$ \\
\hline 10 & $\mathbf{N}+\mathbf{O H}<=>\mathbf{N O}+\mathbf{H}$ & $3.80 \times 10^{13}$ & 0.00 & $0.00 \times 10^{0}$ \\
\hline
\end{tabular}

\section{E. NCC Computations}

Staging was used in the solution process; cold-flow calculations and initial combustion calculations were performed using a single-step chemistry model with Lagrangian spray until a steady state solution was obtained. The final stage of CFD calculations was performed by switching from the one-step chemistry model to the reduced chemistry model; this was done by changing the input chemistry-parameters of the code. It is important to note that no turbulence - chemistry interaction model was used for this case. Based on past experience, this is an adequate engineering modeling assumption.

\footnotetext{
${ }^{*}$ Results will challenge this assumption. However, the cost of running a complex turbulence-chemistry interaction model is very
} prohibitive, even for supercomputers like NASA's Columbia. 
The NCC computations for reacting and non-reacting flow were run in general until the flow residuals were reduced three orders of magnitude. The mass flow rates at the boundary conditions were also monitored as a convergence criterion. Dissipation (JST type) was set at 0.0 for second order dissipation ( $\varepsilon 2$ ) and 0.1 for fourth order dissipation ( 84 ) (ref. 26). The value of $\mathrm{k} 2$, the constant that scales the second order dissipation gradient switch, was set at 0.50 . Setting the second order dissipation to zero is absolutely necessary to accurately resolving flow features, like jets. A CFL number of 1.0 was used. A cubic, non-linear $k-\varepsilon$ model with a variable $C_{m u}$ coefficient was used. This model was selected because of the swirling flow. A dynamic wall function with pressure gradient effects was used to model near wall turbulent flow effects.

Computations were performed on a variety of computer platforms, namely SGI Columbia supercomputer at NASA Ames and clusters (Mac OSX and Linux) at NASA Glenn. The Columbia supercomputer was preferred because it was considerably faster because of its high speed, low-latency interconnect. This interconnect was important because the Lagrangian spray model created a load unbalance in compute nodes. The high speed interconnect seemed to mitigate the load imbalance. It takes approximately one week to complete a single LDI combustion case using 64 processors. After the baseline run was completed, new runs starting from the baseline case took about two days to one week, depending on the number of spray particles used.

\section{Experimental Data}

The experimental data is provided by Jun Cai, S.-M. Jeng, and R. Tacina (ref. 27), and by Yongqiang Fu and San-Mou Jeng (ref. 28). Velocity measurements were taken with a two-component Laser Doppler Velocimetry (LDV) system, temperature measurements were taken with thermocouples, and emissions data was gathered via an isokinetic probe and gas analyzer. Quartz makes up the combustion section. The combustor experiments have significant convective and radiative heat losses. The temperature measurements reported are not corrected to adiabatic conditions. The heat transfer losses will cause a 200 to $300{ }^{\circ} \mathrm{K}$ temperature difference between the experimental data and the NCC computations. Experimental droplet measurements are collected with a Phase Doppler Particle Analyzer (PDPA).

\section{Results and Discussion}

\section{A. Process Overview}

Table 3 shows the CFD calculations performed to date. In Figure 4, streamlines visualize the flow as it passes through the helical swirler and into the combustion chamber. Note the strength of the recirculation zones by the track of the streamlines. Contours of axial velocity are also shown. Blue indicates negative axial velocity (and the recirculation zones) and red indicates positive axial velocity. The recirculation zone size and strength affects combustion stability and emissions. Figure 5 shows the vaporization process. The liquid droplets (small spheres) vaporize before combustion occurs. The fuel vapor is shown by the green iso-surface. This fuel vapor mixes further with air and then burns. Contours of gas temperature along a centerline cut visualize this combustion process. Blue indicates room temperature and red is at the adiabatic flame temperature. Note how the flame shape is bound by the fuel vapor region.

TABLE 3.-SUMMARY OF CFD CALCULATIONS

\begin{tabular}{|c|c|c|}
\hline $\begin{array}{c}\text { Chemistry } \\
\text { model }\end{array}$ & $\begin{array}{c}\text { Number of } \\
\text { droplet groups }\end{array}$ & $\begin{array}{c}\text { Droplet initial } \\
\text { temperature, } \\
{ }^{\mathbf{K}}\end{array}$ \\
\hline 1 Step & 3 & 350 \\
\hline 10 Step & 3 & 350 \\
\hline 10 Step & 9 & 350 \\
\hline 10 Step & 9 & 300 \\
\hline 10 Step & 18 & 350 \\
\hline
\end{tabular}




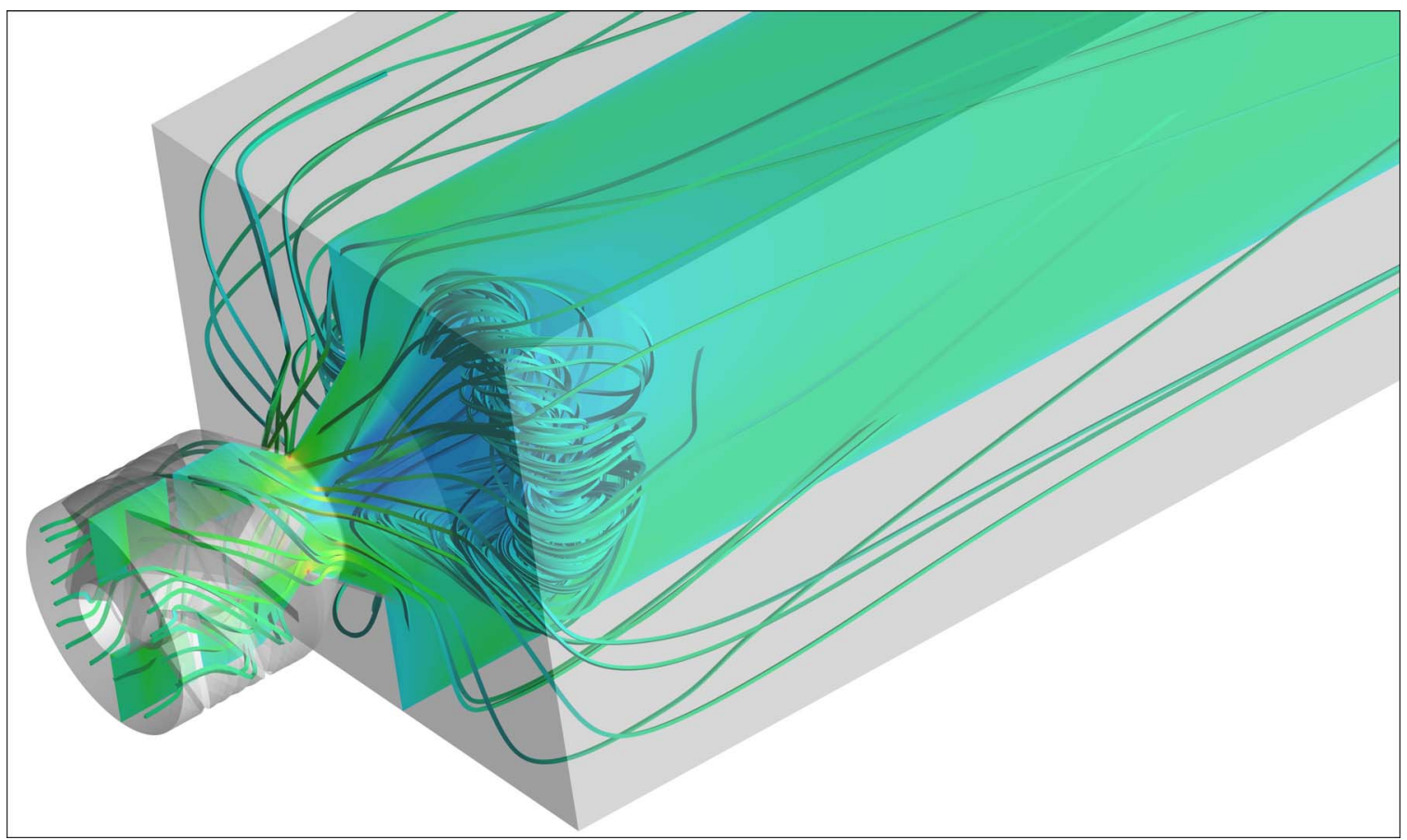

Figure 4.-Flow visualization using streamlines and contours of axial velocity at an axial mid-plane.

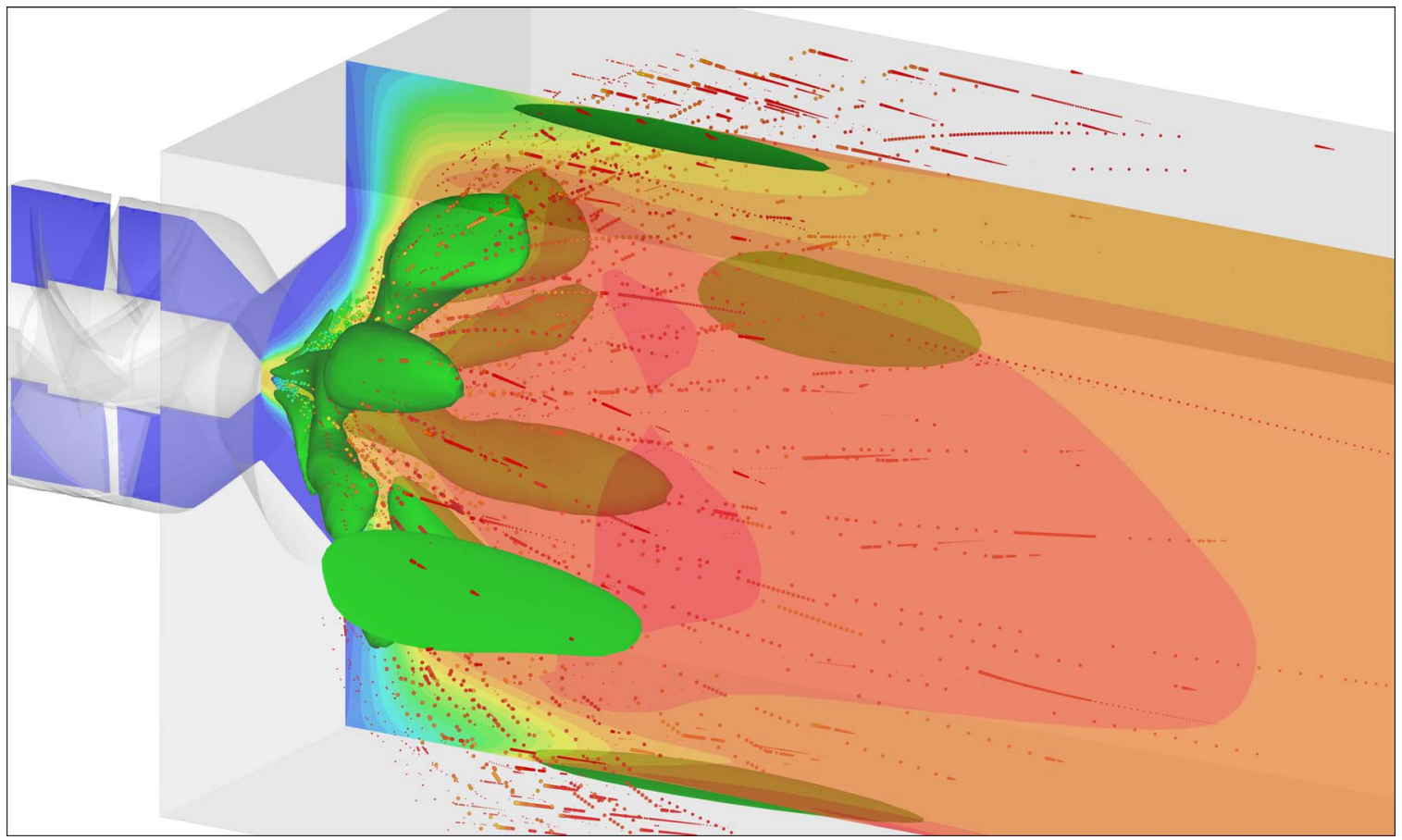

Figure 5.-Flow visualization of the heat release process using the Lagrangian droplet groups, contours of temperature at an axial mid-plane, and iso-surfaces of the fuel mass fraction. 


\section{B. Flow Comparison}

Figure 6 shows a comparison of axial velocity at the centerline. All of the simulations show general agreement with the experimental data, but appear out of phase. The experimental data also shows a dip in axial velocity from 0 to $10 \mathrm{~mm}$ from the combustor face. The calculations do not produce this dip in axial velocity. Figure 7 gives some hints to why calculations do not agree. Error bars show the root mean square (RMS) values of axial velocity of the experimental data and the calculations. (The RMS values for the CFD calculations are assuming isotropic turbulence; RMS values are the same for each velocity and are calculated from the turbulent kinetic energy.) The RMS values are very large in the 0 to $10 \mathrm{~mm}$ range. Given this high turbulent intensity, the turbulence model (and the RANS assumption) will not be able to reproduce this result. Figure 8 shows a spanwise comparison of axial velocity. In general, the calculations trend better with the experimental data further downstream. The $3 \mathrm{~mm}$ location shows a complete disagreement between the experimental data and CFD calculations. This disagreement was also show by the centerline comparison. Both nine droplet group simulations match the data better at the $3 \mathrm{~mm}$ location, but the reason is not understood. Figure 9 shows the comparison with radial velocity for spanwise rakes. The data is reasonable matched in all locations. The simulations performed with more droplet groups tend to match the data better in the 3 and $9 \mathrm{~mm}$ locations. Figure 10 shows a comparison of turbulent kinetic energy along the centerline. (The turbulent kinetic energy for the experimental data was created by duplicating the RMS value for the radial velocity to get the three values needed to calculate the turbulent kinetic energy. The RMS of axial velocity is the other component.) A very interesting result occurs - changing the number of droplet groups drastically changes the turbulent kinetic energy produced. The nine droplet group simulations appears to qualitatively match the experimental data. Why this exactly occurs is unknown. ${ }^{\dagger}$

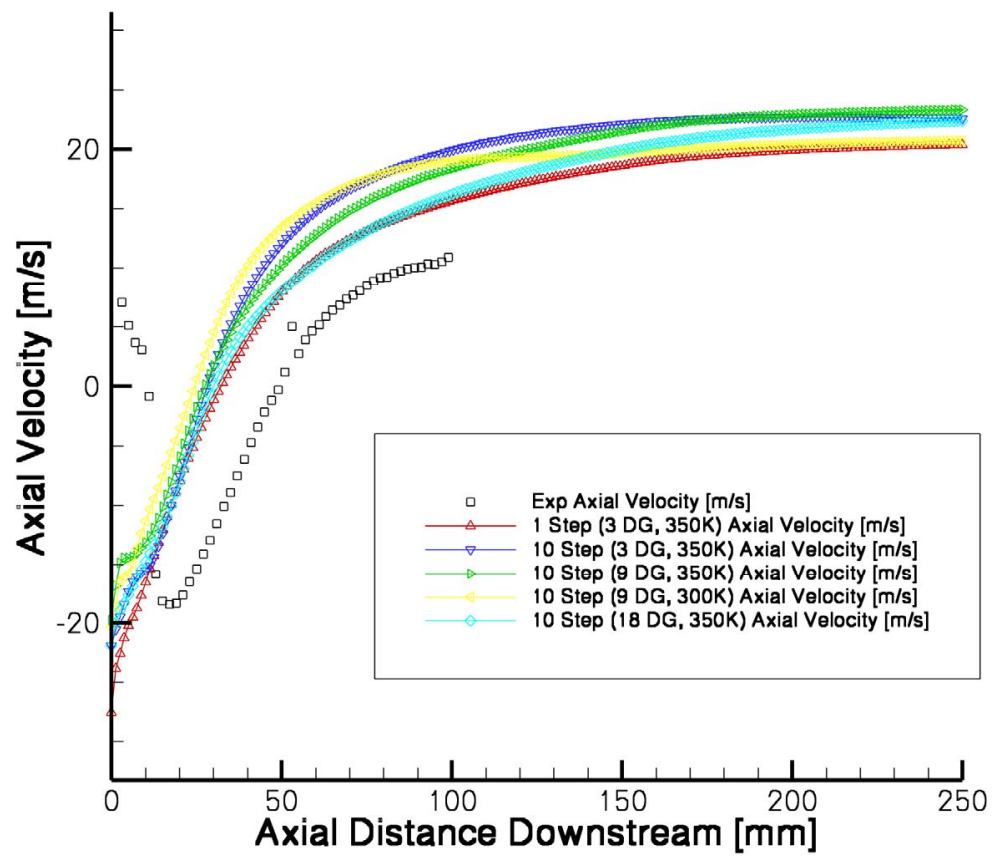

Figure 6.-Comparison of axial velocity versus axial distance at the centerline.

\footnotetext{
${ }^{\dagger}$ While there is no turbulence-chemistry interaction, there is a coupling with the heat release and the turbulence equations. The heat release process essentially modifies the expansion and shear the flow is experiencing. This shear then is an input into the turbulence equations. We do not claim that a turbulence-chemistry interaction is not needed.
} 


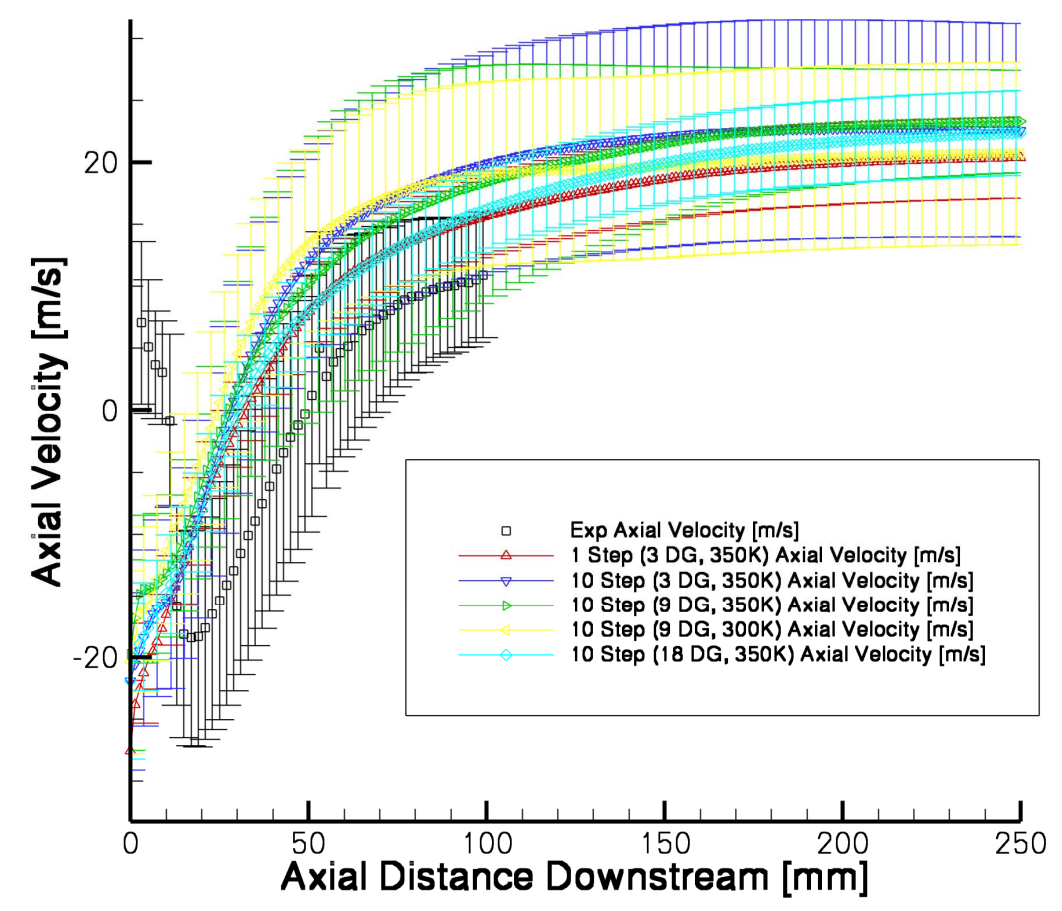

Figure 7.-Comparison of axial velocity with RMS values as error bars versus axial distance at the centerline. 


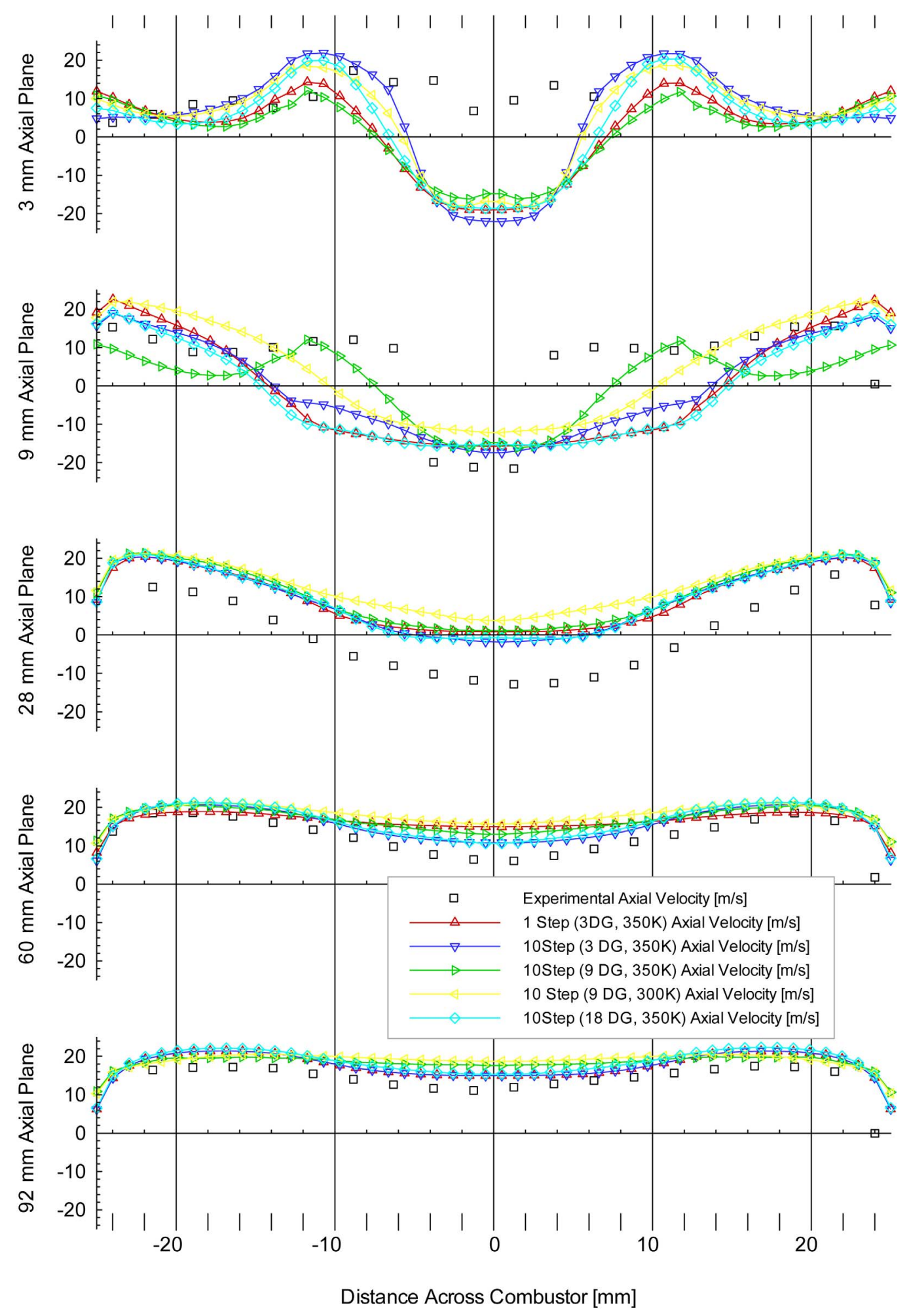

Figure 8.-Comparison of axial velocity versus spanwise distance in the axial $Y-Z$ plane with $Z=0 \mathrm{~mm}$. 


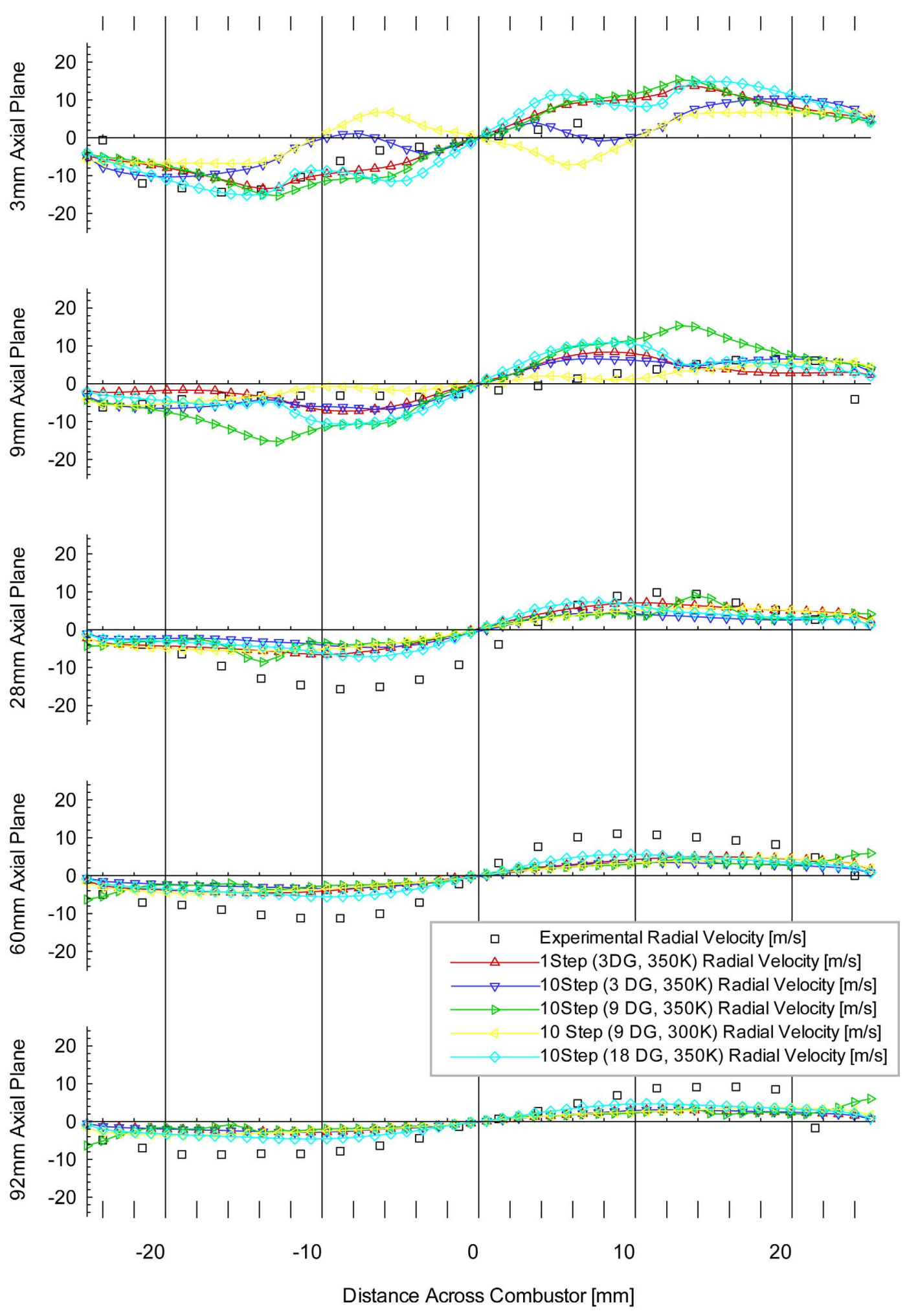

Figure 9.-Comparison of radial velocity versus spanwise distance in the axial $Y-Z$ plane with $Z=0 \mathrm{~mm}$. 


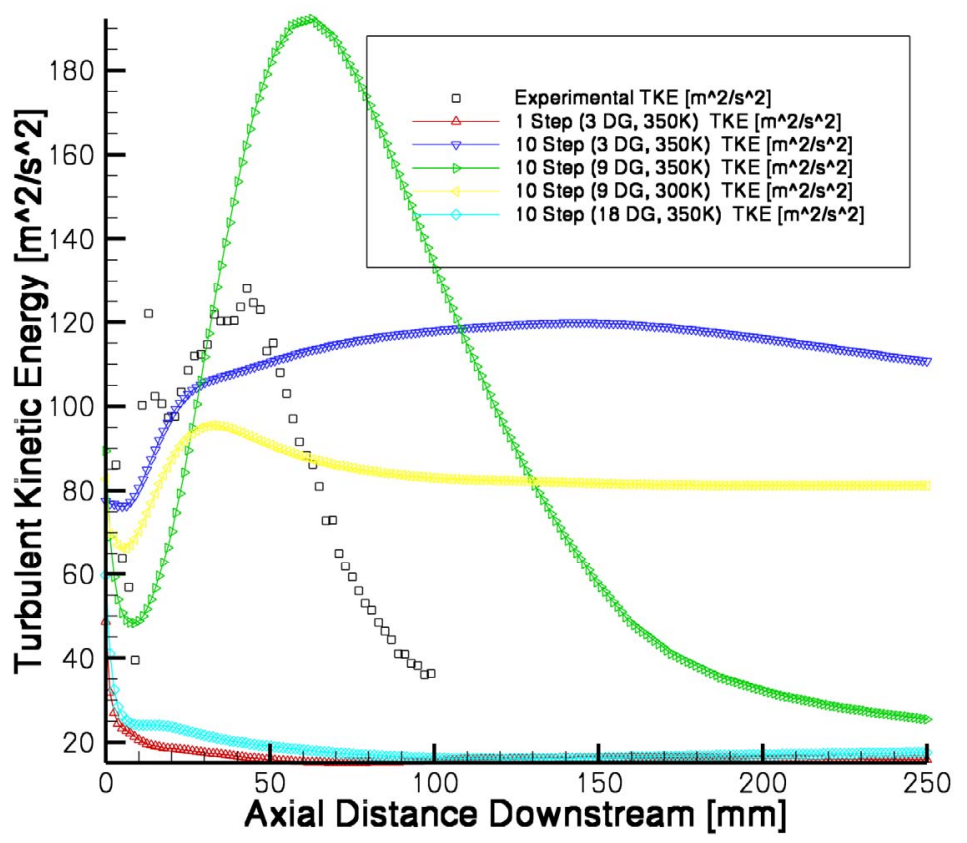

Figure 10.-Comparison of turbulent kinetic energy versus axial distance at the centerline.

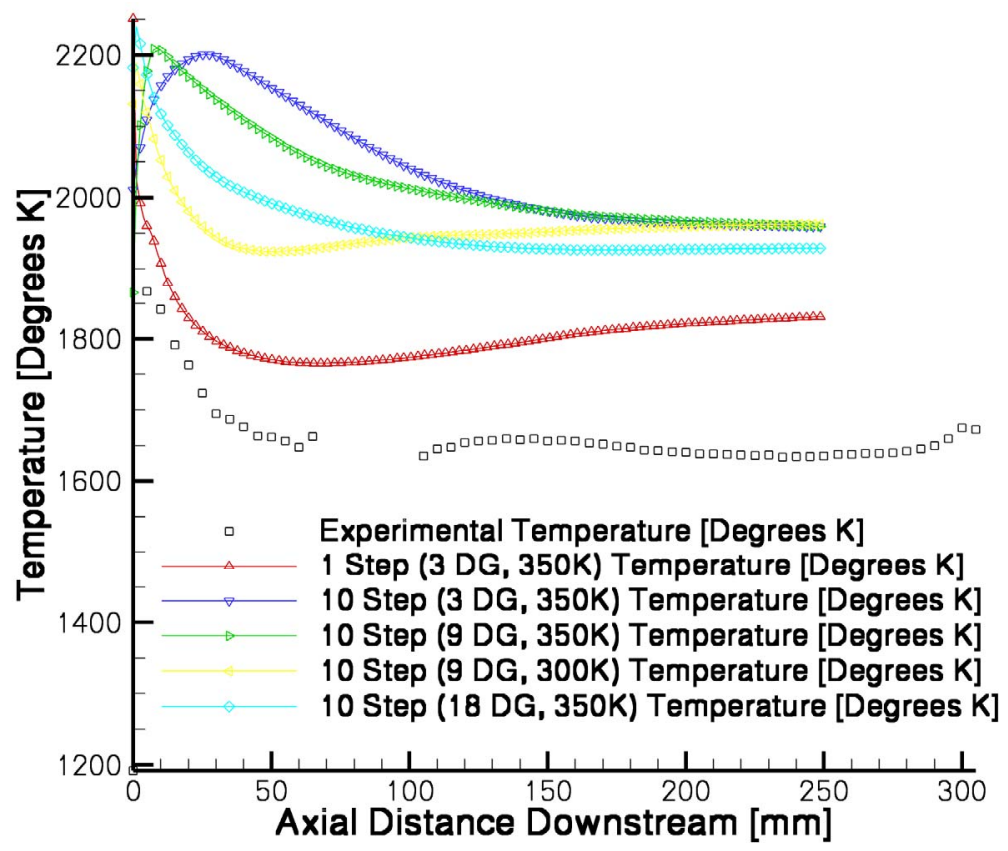

Figure 11.-Comparison of temperature versus axial distance at the centerline.

\section{Temperature Comparison}

As a reminder, experimental temperature is not corrected due to heat losses. Comparing temperature along the center, Figure 11, as great deal of variation is produced. The one-step model shows a fast reaction rate, while the ten-step kinetic model show that process is a function of the number of droplet groups used. While the nine and eighteen droplet group distributions do not have a difference in droplet distribution, the eighteen droplet group computation shows a much faster reaction rate. In general, the CFD calculations at least qualitatively match the shape of the experimental centerline temperature. The more droplet groups used, the better the agreement. Using a lower droplet temperature $\left(300^{\circ} \mathrm{K}\right)$ also seems to affect the solution positively. The spanwise rakes, Figure 12 and 
Figure 13, also compare the CFD calculations against experimental temperature. Generally, the comparison agree more downstream. Near the injector, there is a considerable difference. At the $5 \mathrm{~mm}$ rake, only the calculations with large numbers of droplets agree qualitatively with the experimental data. However, the experimental data shows a strong peak temperature at the center of the rake. None of the CFD calculations reproduced this shape accurately. At the $10 \mathrm{~mm}$ rake, the agreement is better, but only the simulations with adequate droplet distributions (nine and eighteen droplet groups), give the qualitative shape. The shape of the peak temperature is still not reproduced accurately.

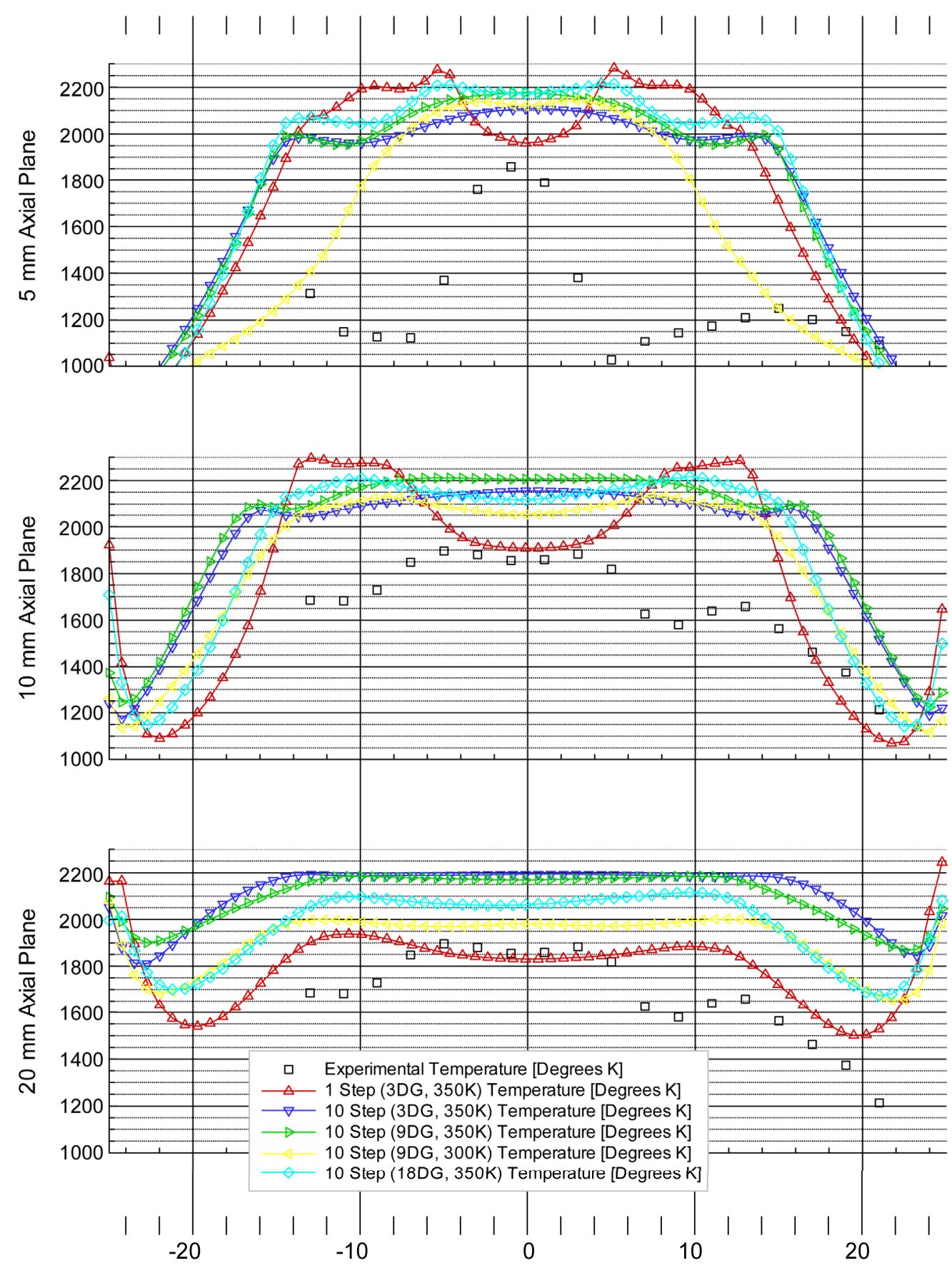

Distance Across Combustor [mm]

Figure 12.-Comparison of temperature versus spanwise distance in the axial $Y-Z$ plane with $\mathrm{Z}=0 \mathrm{~mm}$. 


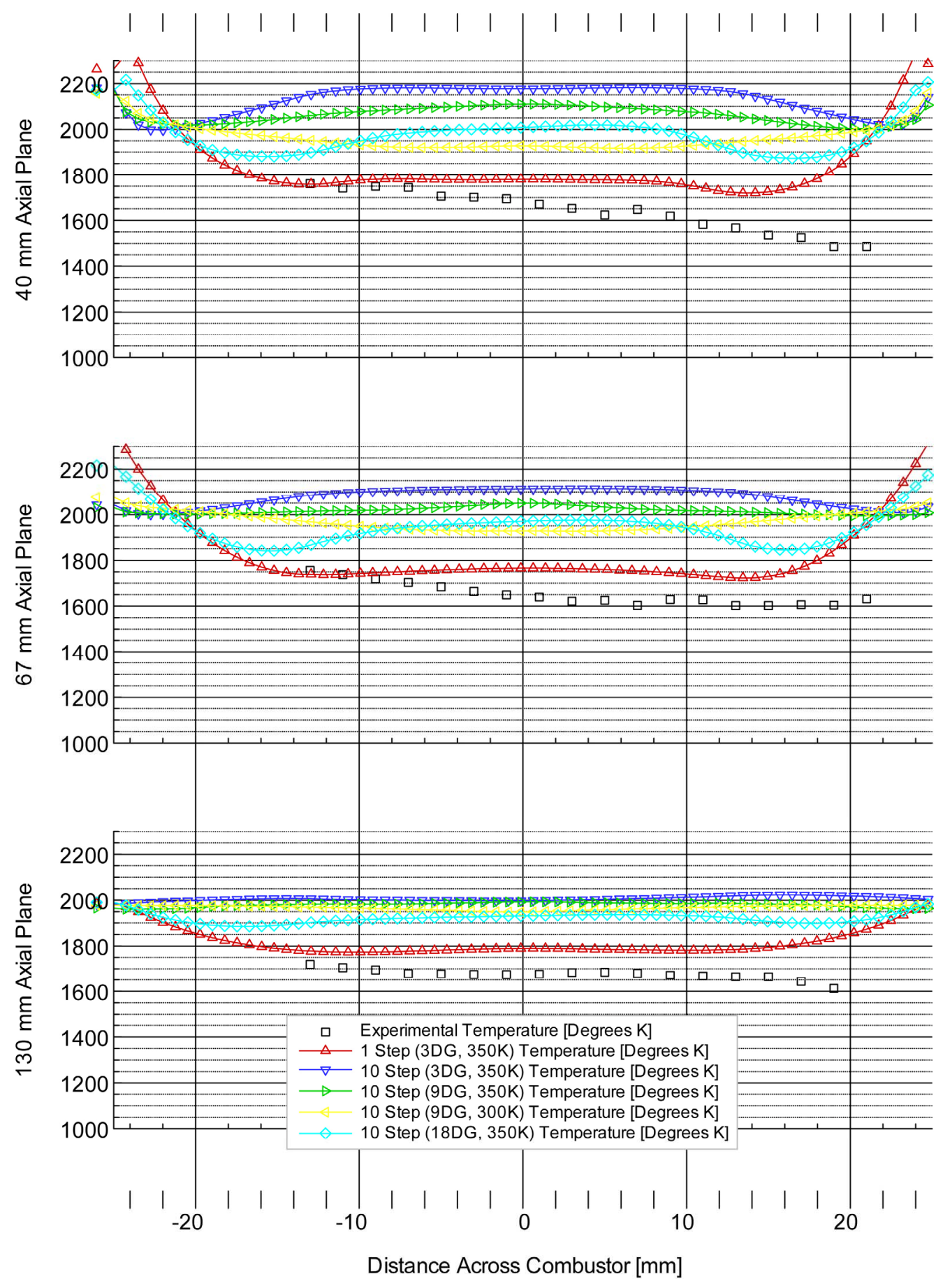

Figure 13.-Comparison of temperature versus spanwise distance in the axial $Y-Z$ plane with $Z=0 \mathrm{~mm}$. 


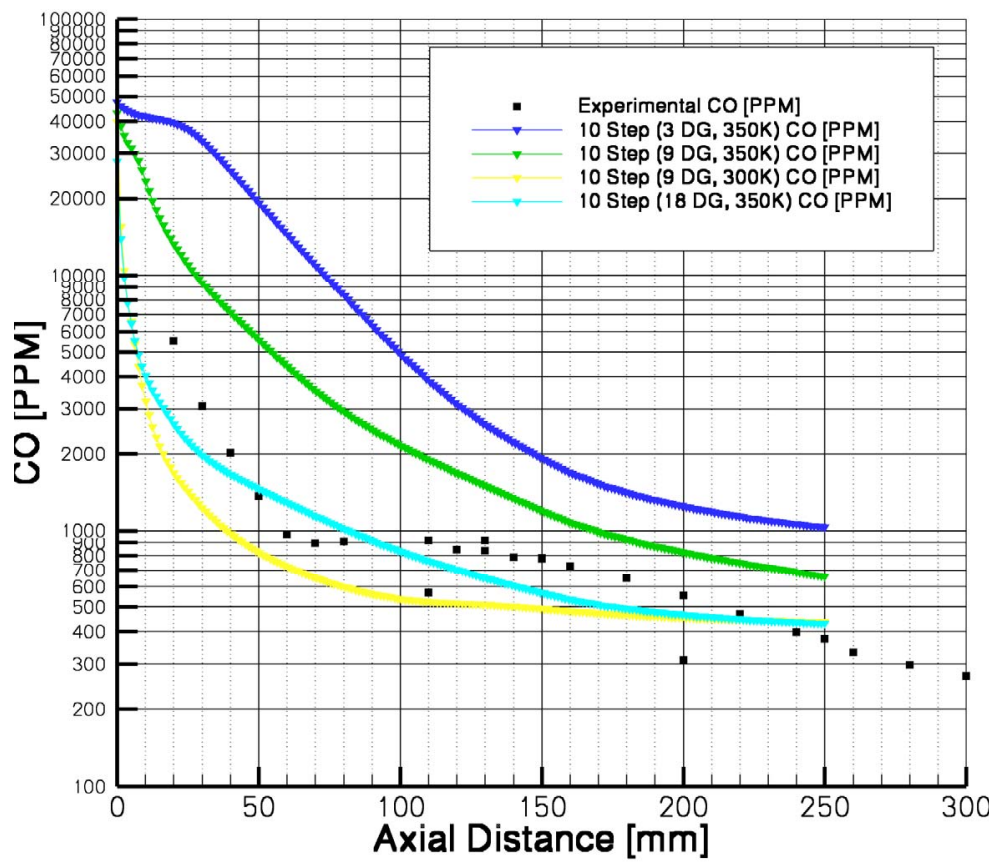

Figure 14.-Comparison of carbon monoxide amounts versus axial distance at the centerline.

\section{Emissions Comparison}

Figure 14 compares the amount of $\mathrm{CO}$ along the centerline. (Please note: the $\mathrm{Y}$ axis is a log scale.) All of the 10 -step simulations reproduce the general amounts of $\mathrm{CO}$. The more droplet groups used, the better the agreement with the experimental data. Using a lower initial droplet temperature seems to positively affect the comparison. We would like to point out that we have not done any error analysis on this data. Measuring $\mathrm{CO}$ is difficult, because it requires an isokinetic condition to prevent $\mathrm{CO}$ from oxidizing to form $\mathrm{CO}_{2}$. Spanwise rakes of $\mathrm{CO}$ are show in Figure 15 Once again, the more droplet groups used, the better the result. Only the simulations using nine and eighteen droplet groups qualitatively agreed with the experimental data, particularly the shapes. While it appears the CFD calculations quantitatively agree with the experiments, for the reasons given above, this may not be correct. Looking at the $\mathrm{NO}_{\mathrm{x}}$ amounts along the centerline, Figure 16, we see that the differences increase while proceeding downstream. Using more droplet groups does not improve the CFD results. Figure 17 shows the spanwise $\mathrm{NO}_{\mathrm{x}}$ amounts. Close to the injector face, the CFD calculations qualitatively agree with the experimental data. Moving downstream from the injector face, the comparison is worse. From this comparison, we believe the ten-step kinetic model is not adequate for predicting amounts of $\mathrm{NO}_{\mathrm{x}}$. 


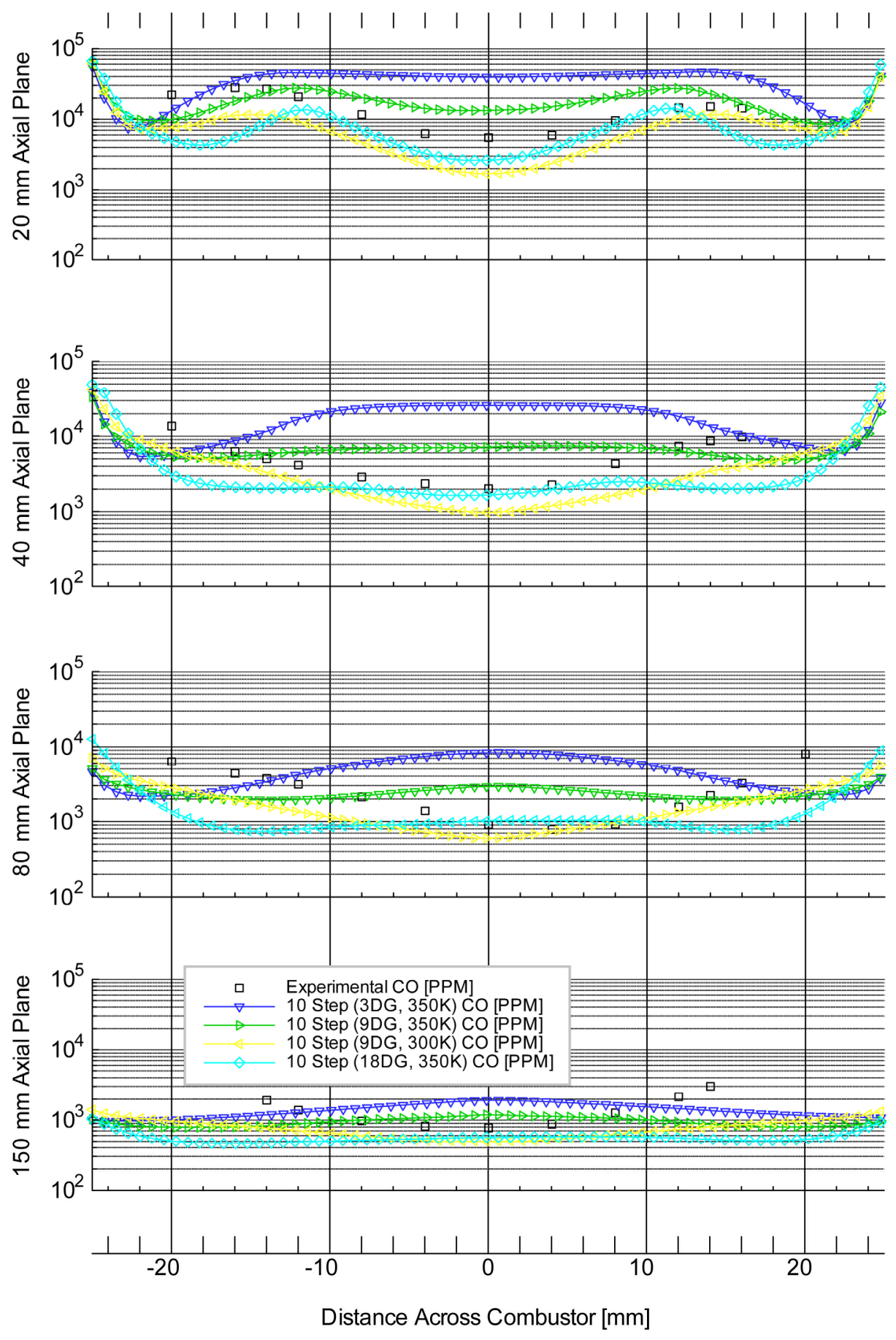

Figure 15.-Comparison of carbon monoxide amounts versus spanwise distance in the axial $Y-Z$ plane with $Z=0 \mathrm{~mm}$. 


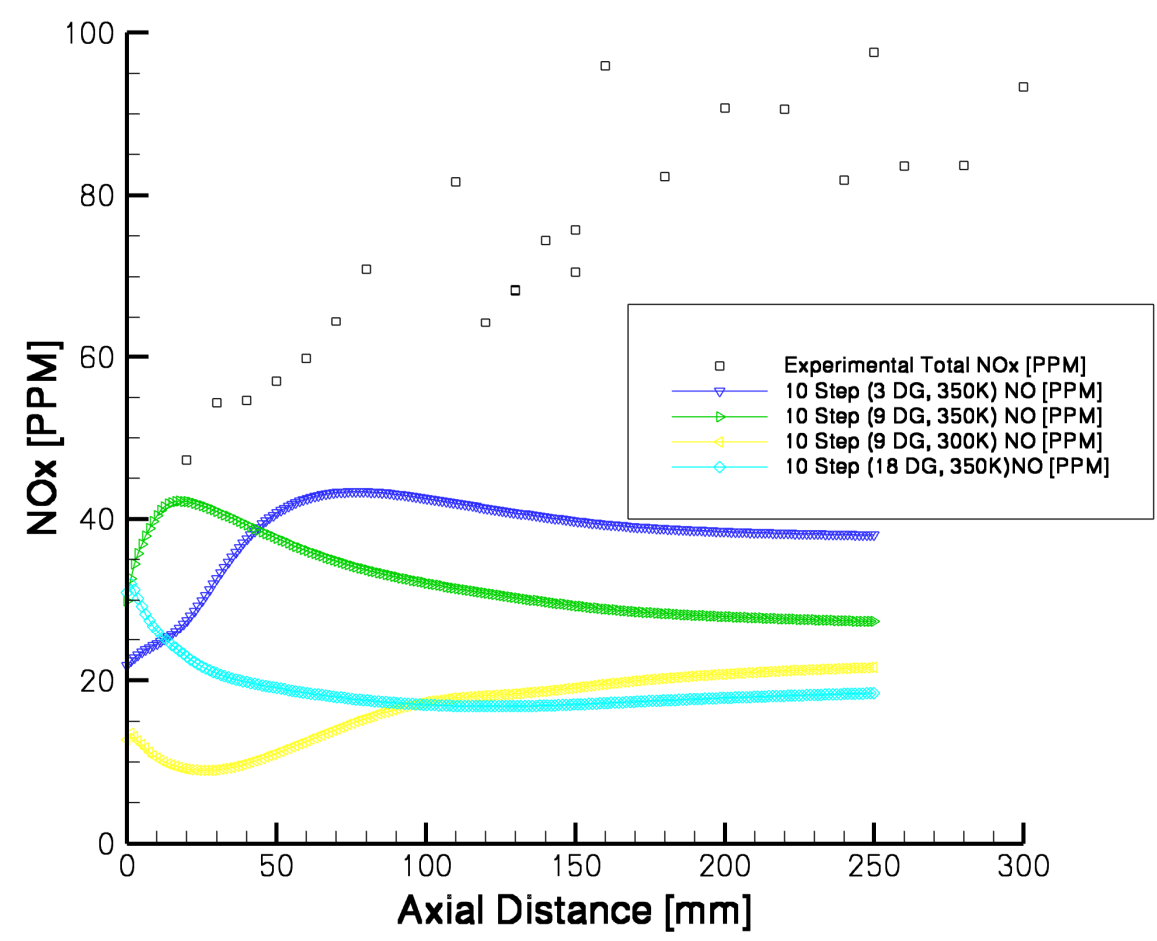

Figure 16.-Comparison of nitrogen oxides amount versus axial distance at the centerline. 


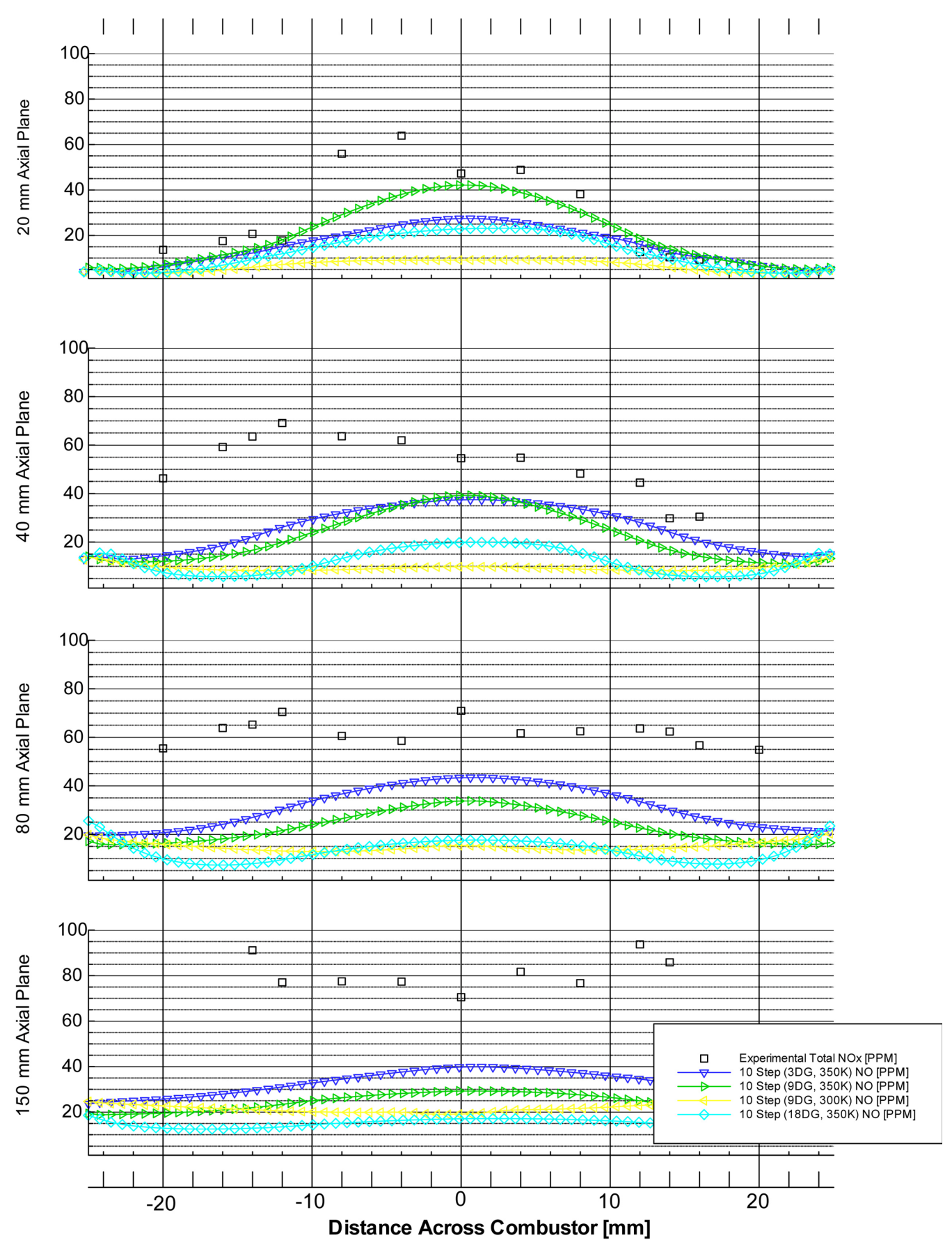

Figure 17.-Comparison of nitrogen oxides amount versus spanwise distance in the axial $Y-Z$ plane with $Z=0 \mathrm{~mm}$. 


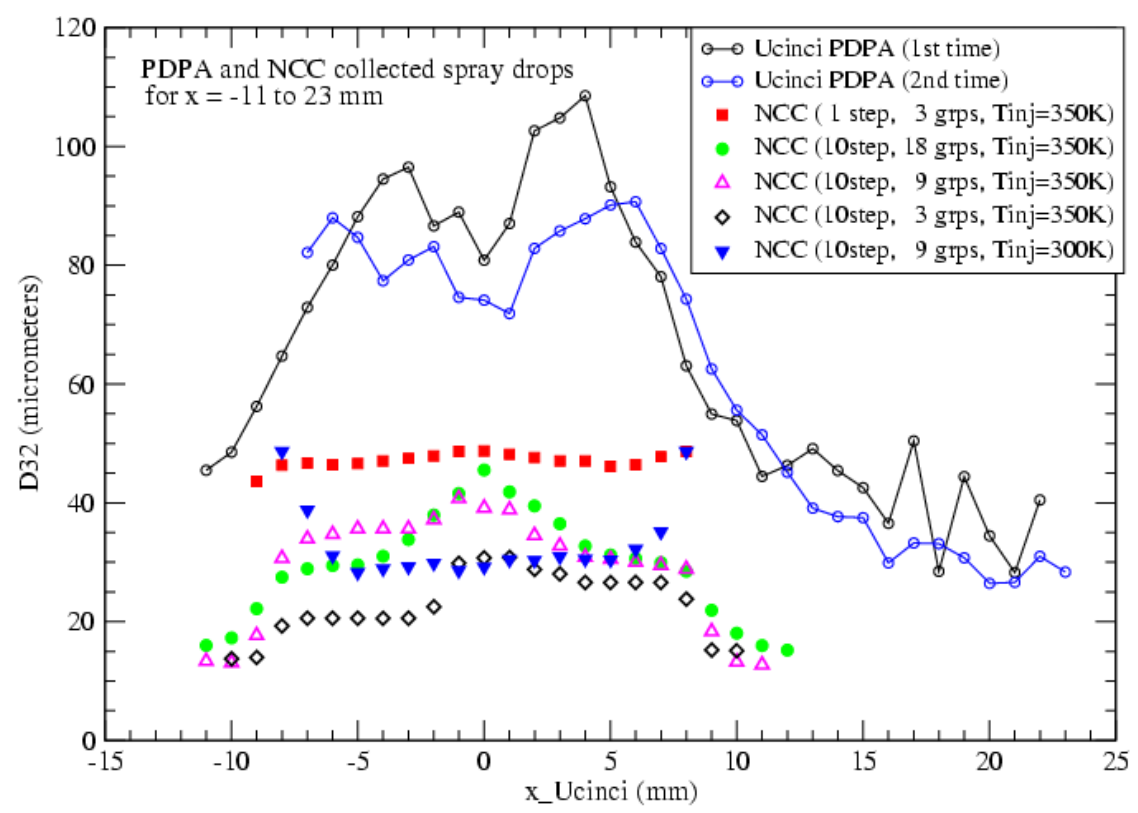

Figure 18.-Sauter Mean Diameter (SMD, D32) for an axial distance of $5 \mathrm{~mm}$ from the combustor face, spanwise rake along the $Y=0 \mathrm{~mm}$.

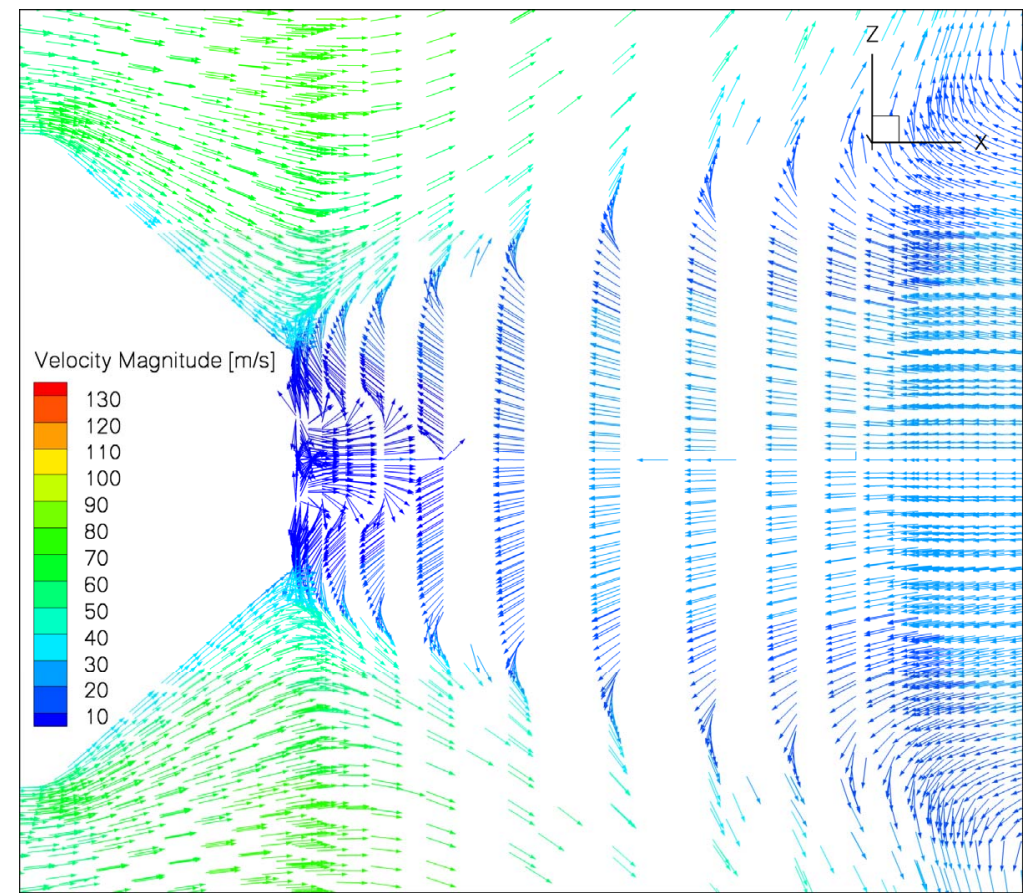

Figure 19.-Velocity vectors colored by velocity magnitude in an axial slice at the $\mathrm{Y}=0 \mathrm{~mm}$ mid-plane.

\section{E. Dropsize and Mesh Resolution-Sources of Error}

Looking at Figure 18, we compare computed Sauter Mean Diameter, after the Lagrangian particle is injected into the simulation. The CFD and experimental data are measured in essentially the same way - by probes to count each droplet size. Details on exactly how this is done will be reported in a later paper. While the overall shape is reproduced by the CFD calculations, the dip in experimental droplet size is not captured by the calculations. Also, the CFD calculations differ by more than a factor of two. We believe the $32 \mu \mathrm{m}$ SMD given to the distribution is too small. For this case, a $70 \mu \mathrm{m}$ droplet size would be more appropriate. Figure 19 shows the recirculation zone, via 
velocity vectors, near the fuel injector tip. The strength of the recirculation zone is large enough to possible cause secondary droplet breakup. For a better comparison in the future, secondary droplet breakup should be used. Looking at the gaseous fuel mass fraction at the injector tip, Figure 20, there is a considerable amount of evaporation that occurs. Computational grid also determines the solution accuracy near the injector tip. Figure 21 shows the mesh spacing near the injector tip. Given the amount of change that occurs, the mesh should be refined in this area.

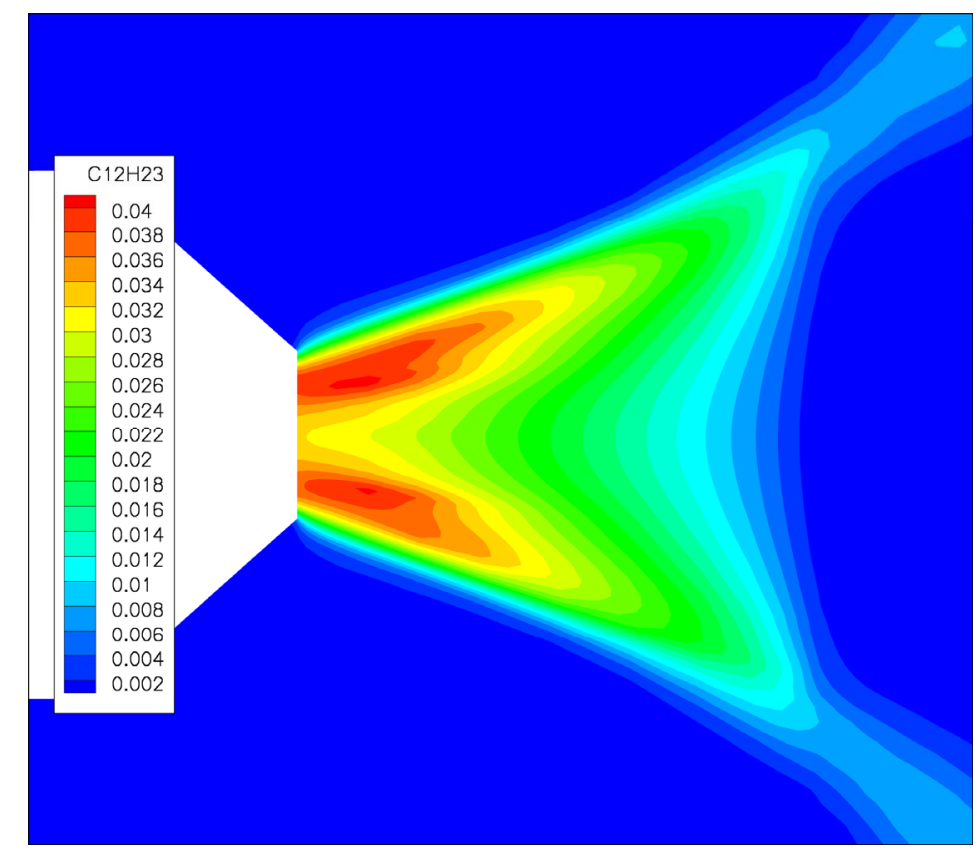

Figure 20.-Contours of fuel mass fraction $\left(\mathrm{C}_{12} \mathrm{H}_{23}\right)$ in an axial slice at the $\mathrm{Y}=0 \mathrm{~mm}$ mid-plane.

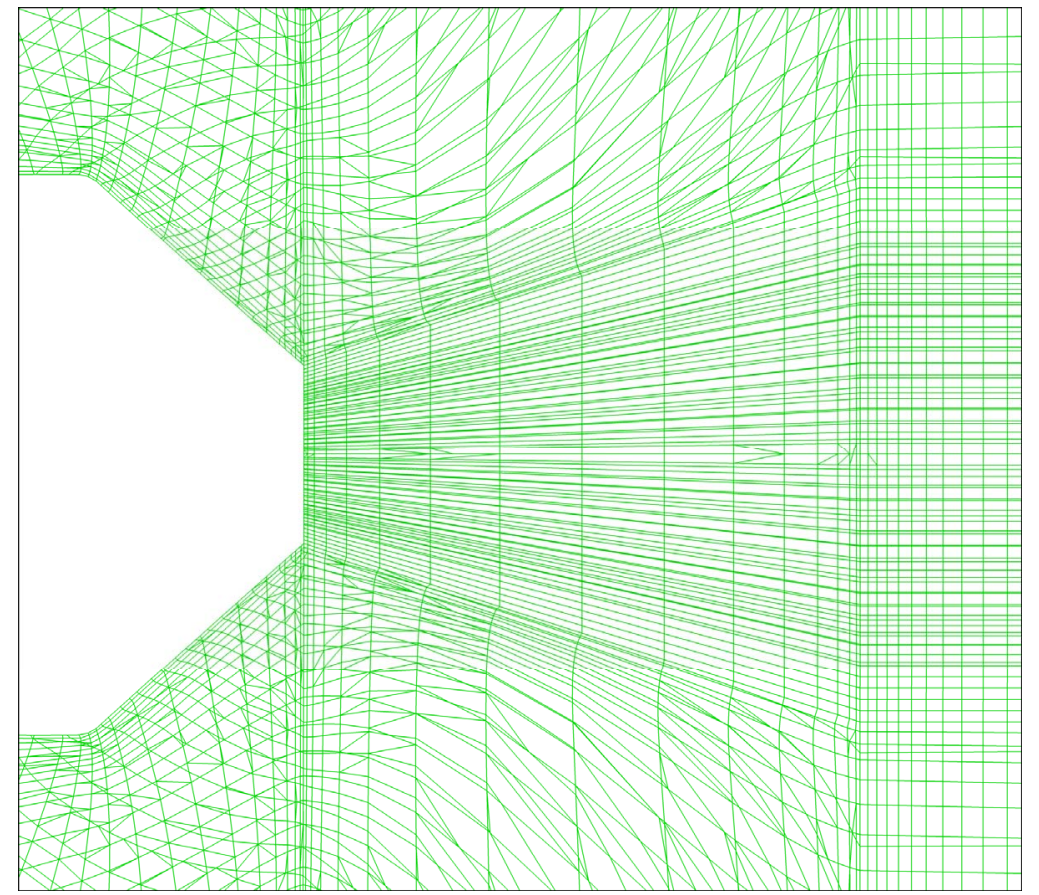

Figure 21.-Approximate visualization of the computational mesh in an axial slice in at the $\mathrm{Y}=0 \mathrm{~mm}$ mid-plane. 


\section{Conclusions}

These CFD calculations are a step forward in anchoring CFD codes, like the NCC, to a swirling, reacting spray flow. The current results are acceptable, but can and will be improved. The improvements that will be made are: using a better reduced Jet-A kinetic mechanism, using a larger Sauter Mean Diameter, adding a secondary droplet breakup model, improving the mesh density near the injector tip, and using a consistent turbulence - chemistry interaction model.

\section{References}

1. Tacina, R., Mansour, A., Partelow, L., Wey, C., "Experimental Sector and Flame-Tube Evaluations of a Multipoint Integrated Module Concept for Low Emission Combustors," GT-2004-53263, ASME Turbo Expo 2004, Vienna, Austria, 2004.

2. Tacina, R., Wey, C., Laing, P., and Mansour, A., "Sector Tests of a Low-NOx, Lean-Direct-Injection, MultiPoint Integrated Module Combustor Concept," GT-2002-30089, 2002.

3. Tacina, R., Wey, C., Laing, P., and Mansour, A., "A Low NOx Lean-Direct Injection, MultiPoint Integrated Module Combustor Concept for Advanced Aircraft Gas Turbines," NASA/TM-2002-211347, Porto, Portugal, July 9-12, 2001.

4. Stubbs, R.M., and Liu, N.-S., (1997), "Preview of the National Combustion Code," AIAA 97-3114, 33 $3^{\text {rd }}$ AIAA/ASME/SAE/ASEE Joint Propulsion Conference and Exhibit, July 6-9, Seattle, WA.

5. Quealy, A., Ryder, R., Norris, A., and Liu, N.-S., (2000), "National Combustion Code: Parallel Implementation and Performance," NASA/TM-2000-209801.

6. Quealy, A., "National Combustion Code Parallel Performance Enhancements," NASA/CR - 2002-211340.

7. Shih, T.-H., Povinelli, L.A., Liu, N.-S and Chen, K.-H., (2000), "Generalized Wall Function for Complex Turbulent Flows," NASA/TM-2000-209936.

8. Chien, K.Y., (1982), "Prediction of Boundary Layer Flows with a Low - Reynolds Number Turbulence Model," AIAA J., vol. 20, no. 1, pp 33-38.

9. Shih, T.-H., Chen, K.-H., Liu, N.-S., Lumley, J.L., (1998), “Modeling of Turbulent Swirling Flows,” NASA TM-113112.

10. Shih, T.-H., Chen, K.-H., and Liu, N.-S., (1998), “A Non-Linear k-epsilon Model for Turbulent Shear Flows," AIAA Paper 98-3983.

11. Raju, M.S., "LSPRAY-II: A Lagrangian Spray Module,"NASA/CR-2004-212958, 2004.

12. S. Venkateswaran, J.M. Weiss, C.L. Merkle, Y.-H. Choi, "Propulsion-Related Flowfields Using Preconditioned Navier-Stokes Equations," AIAA-92-3437.

13. S. Venkateswaran, C.L. Merkle, "Efficiency and Accuracy Issues in Contemporary CFD Algorithms," AIAA2002-2251.

14. Chen, K.-H., Norris, A.T., Quealy, A., and Liu, N.-S., "Benchmark Test Cases for The National Combustion Code.," $34^{\text {th }}$ AIAA/ASME/SAE/ASEE Joint Propulsion Conference and Exhibit, Cleveland, OH, July 13-15, 1998.

15. Chen, K.-H., Norris, A.T., Quealy, A., and Liu, N.-S., "Benchmark Test Cases for the National Combustion Code," $34^{\text {th }}$ AIAA/ASME/SAE/ASEE Joint Propulsion Conference and Exhibit, Cleveland, OH, July 13-15, 1998.

16. Iannetti, A., Tacina, R., Jeng, S.-M., and Cai, J., "Towards Accurate Prediction of Turbulent, ThreeDimensional, Recirculating Flows With the NCC,"NASA/TM-2001-210761, AIAA-2001-0809, 2001.

17. T.-H. Shih, A. Norris, A. Iannetti, C.J. Marek, T.D. Smith, N.-S. Liu, and L.A. Povinelli, NASA Glenn Research Center, Cleveland, OH, "A Study of Hydrogen/Air Combustor Using NCC," AIAA-2001-808, 39th Aerospace Sciences Meeting and Exhibit, Reno, NV, Jan. 8-11, 2001.

18. Iannetti, A.C., Chen, K.-H., "An Initial Comparison of National Combustor Code Simulations Using Various Chemistry Modules With Experimental Gas Turbine Combustor Data," AIAA-2000-0330, $38^{\text {th }}$ AIAA Aerospace Sciences Meeting, Reno, NV, 2000.

19. Davoudzadeh, F., Liu, N.-S., "Validation of the National Combustion Code (NCC)," Presentation, UltraEfficient Engine Technology Program Technical Forum, NASA Glenn Research Center, Cleveland, OH, October 27-29, 2003.

20. Davoudzadeh, F., Liu, N.-S., "Numerical Prediction of Non-Reacting and Reacting Flow in a Model Gas Turbine Combustor," GT2004-53496, Proceedings of the ASME Turbo Expo, Vienna, Austria, 2004.

21. C.K. Westbrook and F.L. Dryer, "Simplified Reaction Mechanisms for the Oxidation of Hydrocarbon Fuels in Flames," Combust. Sci. Technology, vol. 27, p. 31, 1981. 
22. Penko, P.F.; Kundu, K.P.; Siow, Y.K.; and Yang, S.L., "A Kinetic Mechanism for Calculation of Pollutant Species in Jet-A Combustion," AIAA-2000-3035, 2000.

23. Kundu, K.P.; Penko, P.F.; and VanOverbeke, T.J., "A Practical Mechanism for Computing Combustion in Gas Turbine Engines," AIAA-99-2218, 1999.

24. Zeldovich, Y.B. The Oxidation of Nitrogen in Combustion and Explosions, Acta Physicochimica, URSS 2, pp. 577-628, 1946.

25. Fennimore, C.P., 13th Symposium. (Int) Comb., 1971, p.371.

26. Swanson, R.C., and Turkel, E., "Multistage Schemes With Multigrid for Euler and Navier-Stokes Equations," NASA TP-3631, 1997.

27. Cai, J., S.-M. Jeng, S.-M., "The Structure of a Swirl-Stabilized Reacting Spray Issued From an Axial Swirler," AIAA-2005-1424, 43rd AIAA Aerospace Sciences Meeting \& Exhibit, January 10-13, 2005, Reno, NV.

28. Fu, Y., Jeng, S.-M., Tacina, R., "Characteristics of the Swirling Flow Generated by an Axial Swirler," Proceedings of GT2005 ASME Turbo Expo 2005: Power for Land, Sea and Air June 005, Reno-Tahoe, NV. 


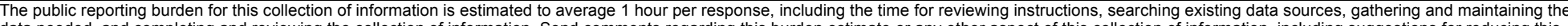

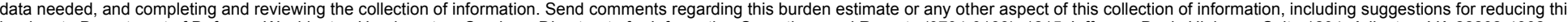

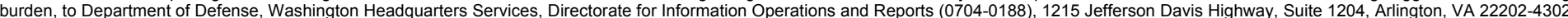

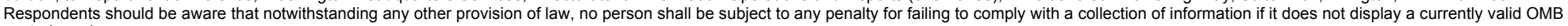
control number.

PLEASE DO NOT RETURN YOUR FORM TO THE ABOVE ADDRESS.
1. REPORT DATE (DD-MM-YYYY)
2. REPORT TYPE
3. DATES COVERED (From - To)

01-10-2008

Technical Memorandum

\section{TITLE AND SUBTITLE}

The Effect of Spray Initial Conditions on Heat Release and Emissions in LDI CFD

Calculations

\section{5a. CONTRACT NUMBER}

5b. GRANT NUMBER

5c. PROGRAM ELEMENT NUMBER

6. AUTHOR(S)

Iannetti, Anthony, C.; Liu, Nan-Suey; Davoudzadeh, Farhad

\section{5d. PROJECT NUMBER}

5e. TASK NUMBER

5f. WORK UNIT NUMBER

WBS 984754.02.07.03.19.02;

561581.02.08.03.16.02

7. PERFORMING ORGANIZATION NAME(S) AND ADDRESS(ES)

National Aeronautics and Space Administration

8. PERFORMING ORGANIZATION

John H. Glenn Research Center at Lewis Field REPORT NUMBER

Cleveland, Ohio 44135-3191

\section{E-16591}

\section{SPONSORING/MONITORS ACRONYM(S) \\ NASA}

National Aeronautics and Space Administration

Washington, DC 20546-0001

\section{SPONSORING/MONITORING} REPORT NUMBER

NASA/TM-2008-215422

\section{DISTRIBUTION/AVAILABILITY STATEMENT}

Unclassified-Unlimited

Subject Categories: 34, 64, and 07

Available electronically at http://gltrs.grc.nasa.gov

This publication is available from the NASA Center for AeroSpace Information, 301-621-0390

\section{SUPPLEMENTARY NOTES}

\section{ABSTRACT}

The mass and velocity distribution of liquid spray has a primary effect on the combustion heat release process. This heat release process then affects emissions like nitrogen oxides (NOx) and carbon monoxide (CO). Computational Fluid Dynamics gives the engineer insight into these processes, but various setup options exist (number of droplet groups, and initial droplet temperature) for spray initial conditions. This paper studies these spray initial condition options using the National Combustion Code (NCC) on a single swirler lean direct injection (LDI) flame tube. Using laminar finite rate chemistry, comparisons are made against experimental data for velocity measurements, temperature, and emissions (NOx, CO).

\section{SUBJECT TERMS}

Computational fluid dynamics; Combustion; Fuel spray; Drops (liquid)

\begin{tabular}{|l|l|l|l|}
\hline \multicolumn{2}{|l|}{ 16. SECURITY CLASSIFICATION OF: } & $\begin{array}{l}\text { 17. LIMITATION OF } \\
\text { ABSTRACT }\end{array}$ \\
\begin{tabular}{|l|l|} 
a. REPORT \\
U
\end{tabular} & $\begin{array}{l}\text { b. ABSTRACT } \\
\text { U }\end{array}$ & $\begin{array}{l}\text { C. THIS } \\
\text { PAGE } \\
\text { U }\end{array}$ & UU \\
\hline
\end{tabular}

18. NUMBER
OF
PAGES
27

19a. NAME OF RESPONSIBLE PERSON
STI Help Desk (email:help@sti.nasa.gov)
19b. TELEPHONE NUMBER (include area code)
301-621-0390



